\title{
Spatial and temporal distribution of tropical phytoplankton species and biomass in the Gulf of Carpentaria, Australia
}

\author{
Michele A. Burford, Peter C. Rothlisberg, YouGan Wang \\ CSIRO Marine Laboratories, PO Box 120, Cleveland, Queensland 4163, Australia
}

\begin{abstract}
The biomass and species composition of tropical phytoplankton in Albatross Bay, Gulf of Carpentaria, northern Australia, were examined monthly for 6 yr (1986 to 1992). Chlorophyll a (chl a) concentrations were highest ( 2 to $\left.5.7 \mathrm{\mu g}^{-1}\right)$ in the wet season at inshore sites, usually coinciding with low salinities $(30$ to $33 \mathrm{ppt})$ and high temperatures $\left(29\right.$ to $\left.32^{\circ} \mathrm{C}\right)$. At the offshore sites chl a concentrations were lower $\left(0.2\right.$ to $\left.2 \mu \mathrm{g} \mathrm{l}^{-1}\right)$ and did not vary seasonally. Nitrate and phosphate concentrations were generally low (0 to $3.68 \mu \mathrm{M}$ and 0.09 to $3 \mu \mathrm{M}$ for nitrate and phosphate respectively), whereas silicate was present in concentrations in the range 0.19 to $13 \mu \mathrm{M}$. The phytoplankton community was dominated by diatoms, particularly at the inshore sites, as determined by a combination of microscopic and high-performance liquid chromatography (HPLC) pigment analyses. At the offshore sites the proportion of green flagellates increased. The cyanobacterium genus Trichodesmium and the diatom genera Chaetoceros, Rhizosolenia, Bacteriastrum and Thalassionema dominated the phytoplankton caught in $37 \mathrm{~mm}$ mesh nets; however, in contrast to many other coastal areas studied worldwide there was no distinct species succession of the diatoms and only Trichodesmium showed seasonal changes in abundance. This reflects a stable phytoplankton community in waters without pulses of physical and chemical disturbances. These results are discussed in the context of the commercial prawn fishery in the Gulf of Carpentaria and the possible effect of phytoplankton on prawn larval growth and survival.
\end{abstract}

KEY WORDS: Tropical phytoplankton - Biomass - Community - Seasonal changes - Gulf of Carpentaria

\section{INTRODUCTION}

The Gulf of Carpentaria is a large, shallow $1<65 \mathrm{~m}$ depth) embayment in tropical northern Australia. Albatross Bay, a shallow ( $<20 \mathrm{~m}$ ) bay in the northeast of the Gulf, has a distinct wet season in summer (October to March), with freshwater addition from flood plains and estuaries, and little or no rain for the rest of the year. Light northeast to northwest monsoons blow in the wet season, southeasterly winds in the dry season. Albatross Bay is within the coastal boundary layer, i.e. a zone of water with a particular physical, biological or chemical property that is different from the offshore water (Wolanski \& Ridd 1990). It may trap freshwater runoff, nutrients and suspended sediments and inhibit mixing between the coastal and offshore waters.

The biomass and productivity of phytoplankton in the Gulf are comparable with those of other tropical
Continental shelf regions (Hallegraeff \& Jeffrey 1984, Rothlisberg et al. 1994). In short-term studies, chlorophyll a concentrations ranged from 0.78 to $2.34 \mathrm{\mu g} \mathrm{l}^{-1}$ throughout the Gulf, but were generally higher and more uniform throughout the water column in shallow waters and stratified near the bottom in deeper waters (Hallegraeff \& Jeffrey 1984). Primary productivity in coastal waters is considerably higher $\left(1430 \mathrm{mg} \mathrm{C} \mathrm{m}^{-2}\right.$ $\mathrm{d}^{-1}$ ) than offshore (660 $\mathrm{mg} \mathrm{C} \mathrm{m}^{-2} \mathrm{~d}^{-1}$ ) (Rothlisberg et al. 1994). The phytoplankton community is dominated by the cyanobacterium genus Trichodesmium and large diatoms such as the genera Rhizosolenia, Chaetoceros, Bacteriastrum and Thalassionema (Hallegraeff \& Jeffrey 1984).

In a 6 yr study of the recruitment dynamics of the prawns Penaeus merguiensis and $P$. semisulcatus (Rothlisberg et al. 1988), the larval, juvenile and adult stages in the estuaries and waters of Albatross Bay 
were examined. Our study focused on the seasonal, spatial and interannual changes in the phytoplankton community, which is both a direct food source for larvae and a link in the food web for juvenile and adult prawns. The biomass and species composition of the phytoplankton community were examined in conjunction with physical and chemical factors to find out which factors govern phytoplankton distribution and abundance in Albatross Bay.

\section{METHODS}

Sample collection. Temperature and salinity measurements were made with a submersible data logger each month between August 1986 and April 1992 at 4 sites in and near Albatross Bay (Fig. 1a). Measurements were not taken in some months and a few sites were not sampled during inclement weather. Wind speed and rainfall data from Weipa were obtained from the Australian Bureau of Meteorology. Wind speed was measured at 09:00 and 15:00 h daily, and rainfall was measured as a daily total. The data were pooled to give monthly totals.

In order to determine the phytoplankton pigment composition, water samples of 2 to 51 were collected concurrently with the temperature and salinity measurements at the 4 sites over 6 yr (Fig. 1a) with a 51 Niskin bottle, at mid-depth, i.e. $5 \mathrm{~m}$ at Site a, $6 \mathrm{~m}$ at
Site b, $18 \mathrm{~m}$ at Site c, $22 \mathrm{~m}$ at Site $\mathrm{d}$. In the last $2 \mathrm{yr}$, bottom samples were also taken. Samples for pigment analysis were filtered on deck through GF/F glass fibre filters, which were frozen immediately. In the last year (August 1991 to April 1992), the supernatant was also collected and frozen for phosphate, nitrate+nitrite and silicate analyses.

Collections of larger phytoplankton species were made at the 4 sites (Fig. 1a) with surface-to-bottom drops of a $0.6 \mathrm{~m}$ diameter, $37 \mu \mathrm{m}$ mesh free-fall net (Heron 1982). They were immediately preserved with $2 \%$ formaldehyde buffered with hexamine.

In addition to the monthly sampling, 2 cruises were made to study vertical and horizontal changes in phytoplankton pigments in more detail, and size fractionation of the phytoplankton community. In February 1990, 21 sites in Albatross Bay were sampled at $2 \mathrm{~m}$ depth intervals for phytoplankton pigment analysis (Fig. 1b). Salinity and temperature profiles were recorded. Water samples of 2 to 51 were collected, the phytoplankton filtered onto GF/F glass fibre filters and the filters immediately frozen for pigment analysis. In February 1991, water samples were filtered by sizefractionating through $0.6,2$ and $10 \mu \mathrm{m}$ pore size polycarbonate filters and the filters were immediately frozen.

Nutrient analyses. Frozen filtered samples were collected at 4 sites on 9 occasions in the final year of sampling, 6 of these during the wet season; they were
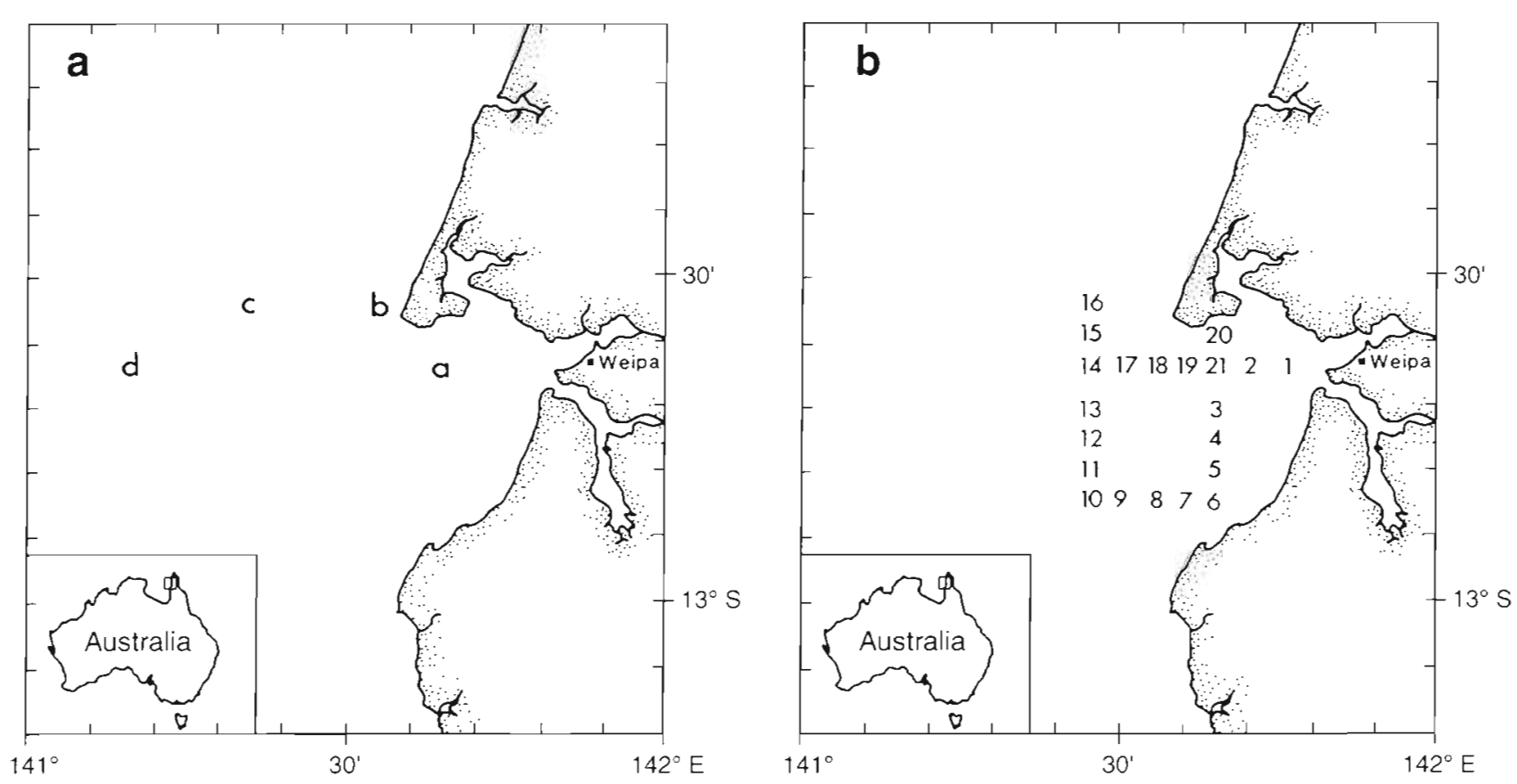

Fig. 1 Sites in Albatross Bay, Gulf of Carpentaria, Australia, sampled (a) monthly trom August 1986 to April 1992, (b) in February 1990 
thawed in the laboratory and analysed by the Strickland \& Parsons (1972) method for nitrate+nitrite, phosphate and silicate.

Identification of $37 \mathrm{\mu m}$ mesh net phytoplankton. In the laboratory, samples of phytoplankton caught by net were shaken and 2 subsamples removed for examination under a Wild Leitz M20 microscope under phase-contrast conditions at 200 and $400 \times$ magnification. Depending on the concentration of the sample, about 10 scans were done across two $22 \times 22 \mathrm{~mm}$ cover slips. Genera were identified from Allen \& Cupp (1935) and Taylor (1976). The samples were quantified by grouping a list of potential genera (Hallegraeff \& Jeffrey 1984) into 3 categories: dominant (genus present in every field of view at $200 \times$ magnification); common (genera observed more than 5 times in the total number of scans, but less frequently than dominant genera) and rare (genus observed no more than 5 times in the total number of scans).

The dominant, common and rare categories were classified numerically as 3,2 and 1 respectively. The mean and standard deviation for each genus were calculated from 242 samples, the result of nearmonthly sampling at 4 sites from May 1986 to April 1992. Mean abundances of $>2$ were classified as dominant, $>1$ to 2 were classified as common, and 1 or less as rare. Of 70 genera, $59(83 \%)$ had a mean abundance of less than 1.0 , and 27 (38\%) had a mean abundance of less than 0.1 . Only the 44 genera with a mean greater than 0.1 were used for further analysis (Field et al. 1982).

All statistical analyses were done with SAS software (Release 6.07). The Wilk's Lambda statistics were used to approximate $F$ statistics for multivariate hypothesis testing (Seber 1984). The effect of site, season and year on the abundance of net phytoplankton was examined. The Bray-Curtis dissimilarity indices were used for cluster analysis and multidimensional scaling (MDS) of the net phytoplankton genera (Clarke 1993). Based on the dissimilarity indices, the genera were classified into groups. The dimension coefficients for 4 sites obtained from the MDS were then plotted to see how similar they were in terms of species abundance. The configuration of the MDS (the coordinates of each genera) was then plotted to determine the similarity of genera in terms of abundance.

Pigment analyses. The samples were analysed in the laboratory within 1 mo of sampling. Each sample was sonicated in $100 \%$ methanol on ice with a Branson ultrasonic probe for $1 \mathrm{~min}$ in the dark, and then filtered through a $0.2 \mu \mathrm{m}$ pore size filter to remove particulates. The extract was collected and injected into a high-performance liquid chromatography (HPLC) system. A methanol: water : ethyl acetate gradient solvent system and RP-C18 column were used. For details of this technique see Burford \& Pollard (1994). The spectra and HPLC retention times of the various pigments were compared with those of pigments previously isolated from standard algal cultures (Burford et al. 1994).

\section{RESULTS}

\section{Phytoplankton seasonality and hydrological environment}

During the 6 yr of monthly sampling in Albatross Bay, water temperatures at the innermost site (Site a) ranged from 25 to $27^{\circ} \mathrm{C}$ in the dry season (April to September), to 30 to $32^{\circ} \mathrm{C}$ in the wet season (October to March) (Fig. 2a). The temperature range was the same at Site b, and at Sites $\mathrm{c}$ and d it was 25 to $31^{\circ} \mathrm{C}$ overall;
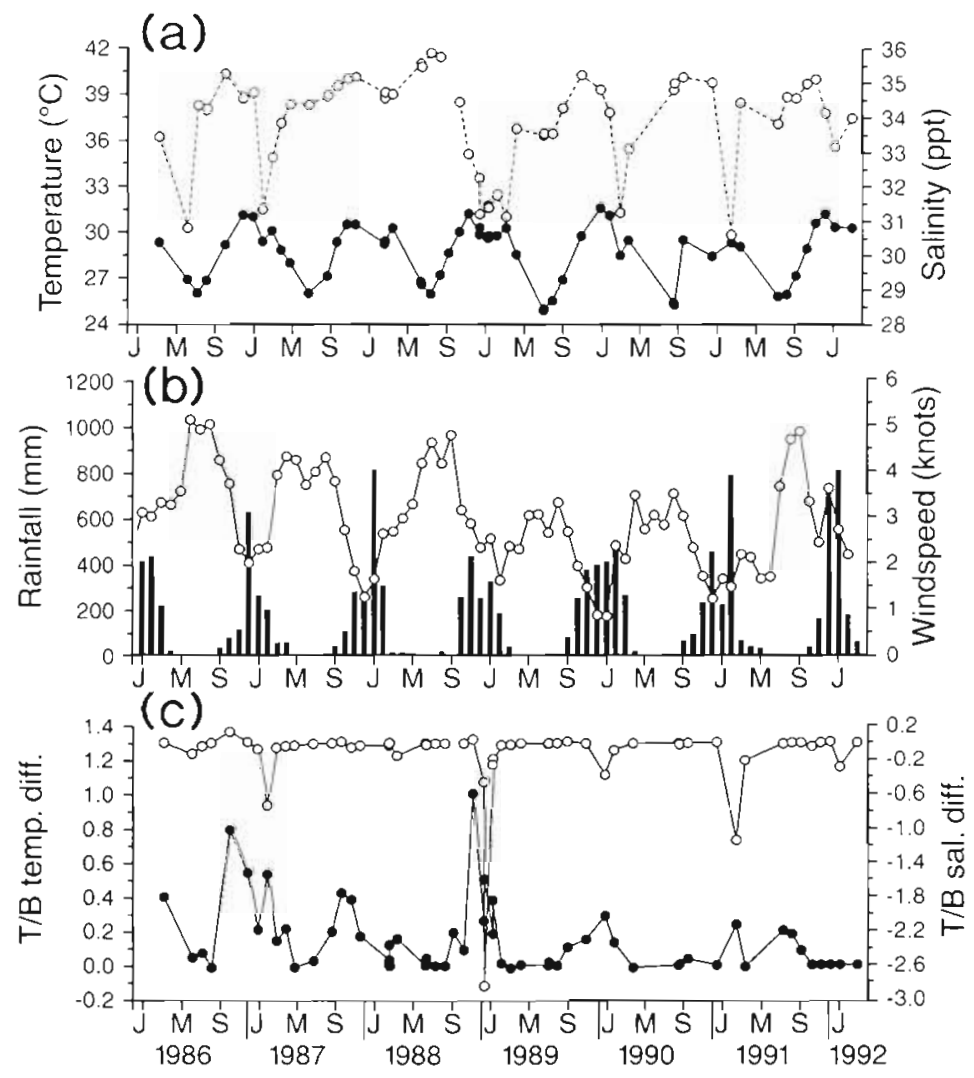

Fig. 2. Albatross Bay, Site a. (a) Mean temperatures $(\bullet)$ and mean salinity (o) in the water column. (b) Total monthly rainfall (bars) and windspeed (o) at Weipa, Gulf of Carpentaria. (c) Top/bottom temperature $(\bullet)$ and salinity (0) differences from April 1986 to April 1992. J: January; M: May; S: September 
however, seasonal differences were not as great. The rainfall, most of which fell in the wet season, increased output from the rivers emptying into Albatross Bay and lowered salinities from 35 to $36 \mathrm{ppt}$ in the dry season to 31 to $32 \mathrm{ppt}$ in the wet season (Fig. 2a, b). The salinity range was the same at Site $b$, and at Sites $c$ and $d$ it was 32 to 36 ppt overall.

The stratification of the water column was generally weak, as indicated by the small differences in surfaceto-bottom salinity and temperature (Fig. 2c); only in January 1989 and March 1991 was there a significant surface-to-bottom difference in salinity. Surface-tobottom temperature differences did not necessarily coincide with surface-to-bottom salinity differences and reflect warming of surface waters in the summer wet season during periods of low wind mixing (Fig, 2b). The monthly wind speed at Weipa was higher in the dry season than in the wet season (Fig. 2b).

Chlorophyll a (chl a) concentrations at Site a ranged from 0.1 to $2.5 \mu \mathrm{g} \mathrm{I}^{-1}$ over the 6 yr of sampling (Fig. 3). At Site $b$, they ranged from 0.5 to $5.7 \mathrm{\mu g} \mathrm{l}^{-1}$, decreasing at the offshore sites to usually less than $1 \mu \mathrm{gl}^{-1}$ at Site $\mathrm{d}$. Concentrations were highest in the wet season at the 2 innermost sites ( $a$ and $b$ ) but seasonality was not apparent at the 2 offshore sites (c and d) during the 6 yr.
Table 1 Correlation between chl a and the environmental factors temperature, salinity and rainfall. $p<0.05$

\begin{tabular}{|lllll|}
\hline & \multicolumn{4}{c|}{ Chl $a$} \\
& Site $a$ & Site b & Site c & Site d \\
\hline Temperature & 0.179 & 0.256 & 0.087 & 0.149 \\
Salinity & 0.068 & 0.223 & 0.249 & 0.102 \\
Rainfall & $0.490^{\circ}$ & 0.398 & 0.365 & 0.343 \\
\hline
\end{tabular}

In the last 2 yr, samples were taken at the bottom of the water column in addition to mid-depth. In general, concentrations were only slightly higher than those at mid-depth, reflecting a well-mixed water column (Fig. 3). Occasionally concentrations were substantially higher at the bottom when the water column was stratified. For example, in November $1990 \mathrm{chl}$ a concentrations were higher at the bottom than at middepth at all sites (Fig. 3).

The pattern of chl a concentrations over the 6 yr was compared with those of the environmental variables temperature, salinity and rainfall. Chl a was positively correlated with rainfall at Site a $(r=0.49, \mathrm{p}<0.05)$, but not at the sites further offshore (Table 1). While there was a trend of higher chl a concentrations in the wet season when temperature was higher and salinity was lower, there was no significant correlation with either temperature or salinity. The seasonal differences in temperature and salinity became less marked at consecutive sites of fshore.

\section{Nutrients}

In 1991-92, nitrate plus nitrite, phosphate and silicate were sampled monthly for $9 \mathrm{mo}, 6$ mo of which were in the wet season. The concentrations varied considerably from month to month, but there were insufficient data to detect any seasonal trends (e.g. Site b; Fig. 4). The average phosphate concentrations over the period were similar at Sites $a_{1} c$ and $d$, ranging from 0.10 to $3.0 \mu \mathrm{M}$ (Table 2). At Site b concentrations were somewhat lower, ranging from 0.09 to $0.47 \mu \mathrm{M}$. Nitrate/nitrite concentrations were highest at Site $a$, which

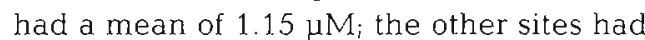
means of $0.55,0.67$ and $0.67 \mu \mathrm{M}$. Silicate concentrations were highest at the inshore sites ( $a$ and $b$ ), which had means of 6.66 and $7.40 \mu \mathrm{M}$ respectively, and decreased offshore, where the means were 4.98 and $3.85 \mu \mathrm{M}$. The ratio of nitrate to phosphate
Fig. 3. Chl a concentrations at 4 sites in Albatross Bay, sampled monthly from April 1986 to April 1992. Bars are mid-depth concentrations; (o) bottom concentrations; $(*)$ a chl a concentration of $5.7 \mu \mathrm{g} \mathrm{I}^{-1} \mathrm{~J}$ : January $\mathrm{M}$ May: S: September. Months in which sampling did nol occur have no bars 


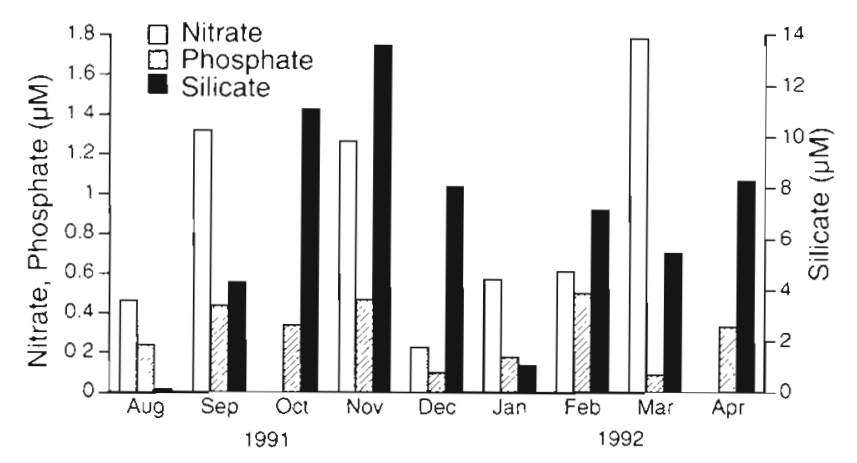

Fig. 4. Nitrate, phosphate and silicate concentrations at the bottom (12 m) of Site b in Albatross Bay from August 1991 to April 1992

ranged from 0.10 to 20 , but was generally less than 4 (Table 2).

\section{Net phytoplankton}

A total of 70 phytoplankton genera were identified from the $37 \mu \mathrm{m}$ mesh net samples taken at the 4 sites in Albatross Bay (Table 3 ). There were 44 diatom genera, 24 dinoflagellate genera, 1 cyanobacterium genus and 1 prymnesiophyte genus. Based on mean abundance (i.e. 2 to $3=$ dominant, 1 to $<2=$ common and 0 to $<1=$ rare) of the 10 most common genera, 9 were diatoms, e.g. Rhizosolenia, Chaetoceros and Thalassionema, and 1 was a cyanobacterium, Trichodesmium (Table 3). The dinoflagellates were generally rare, i.e. a mean abundance of less than 1 . A total of 42 genera with a mean abundance greater than 0.100 were examined in more detail.

There were significant differences $(p<0.01)$ in the relative abundance of phytoplankton from the inshore and offshore sites, at different seasons and years

Table 2. Mean and range of phosphate $\left(\mathrm{PO}_{4}\right)$, nitrate/nitrite $\left(\mathrm{N}_{\mathrm{OXY}}\right)$, nitrate to phosphate ratio $\left(\mathrm{N}_{\mathrm{OXY}}: \mathrm{PO}_{4}\right)$ and silicate $\left(\mathrm{SiO}_{3}\right)$ concentrations $(\mu \mathrm{M})$ at 4 sites in Albatross Bay, Gulf of Carpentaria, sampled at mid depth and bottom, monthly from August 1991 to April 1992

\begin{tabular}{|cccccc|}
\hline Site & $\mathrm{PO}_{4}$ & $\mathrm{~N}_{\mathrm{OXY}}$ & $\mathrm{N}_{\mathrm{OXY}}: \mathrm{PO}_{4}$ & $\mathrm{SiO}_{3}$ & $\mathrm{n}$ \\
\hline $\mathrm{a}$ & 0.38 & 1.15 & 3.0 & 6.66 & 17 \\
& $0.13-2.27$ & $0.06-3.68$ & & $1.74-10.40$ & \\
$\mathrm{~b}$ & 0.26 & 0.67 & 2.6 & 7.40 & 18 \\
& $0.09-0.47$ & $0-1.78$ & & $1.06-13.00$ & \\
$\mathrm{c}$ & 0.34 & 0.67 & 2.0 & 4.98 & 18 \\
& $0.10-2.63$ & $0-2.74$ & & $1.01-10.00$ & \\
$\mathrm{~d}$ & 0.37 & 0.55 & 1.5 & 3.85 & 18 \\
& $0.10-3.00$ & $0-2.35$ & & $0.19-8.41$ & \\
\hline
\end{tabular}

(Table 4). However, the genera had a similar seasonal pattern at the 4 sites since the interaction between season and site was not significant. Analysis by MDS showed clear differences between inshore and offshore sites in the abundance of the 44 genera (Fig. 5). The MDS configuration plot for all genera (dimension 1 by dimension 2) appears to show 4 distinct groups (Fig. 6). All the most common genera present in the largest cluster were ubiquitous and did not appear to be closely linked with individual sites. One group was more closely associated with Sites c and d. Another group was more closely associated with Sites a and b. The ubiquitous diatom genus Skeletonema was not associated with any group.

Comparing the means of individual genera for the wet and dry seasons we found that the differences were explained by only a few genera, most notably the cyanobacterium Trichodesmium. It was one of the most abundant genera and bloomed in the wet season each year, becoming rare or absent during the dry season. Trichodesmium was dominant more frequently at the offshore sites, where blooming generally began in August/September and lasted for 3 to 6 mo (Fig. 7).

As a group, diatoms were more constant in their abundance and distribution. The dominant diatom genera varied considerably in the timing and duration of their blooms (Fig. 7). At the 2 inshore sites, Rhizosolenia had extended periods of dominance - up to 5 mo - but these were not related to season. This genus was often observed to have symbiotic relationships with the nitrogen-fixing cyanobacterium Richelia. In 1989-90, Rhizosolenia was particularly abundant, while the other diatom genera had a relatively low abundance. Chaetoceros, Thalassionema and Bacteriastrum had periods of dominance at all sites; however these were less prolonged than those of Rhizosolenia and the timing varied from genus to genus.

Dinoflagellates were the most stable group. Their overall abundance was lower, and did not vary markedly between seasons and inshore/offshore.

Principal component analysis was carried out to determine the degree of association between the genera. The association was not strong, i.e. the first 10 principal components explained only $52 \%$ of the variation, which suggests that the patterns of abundance for individual genera are relatively independent of each other.

\section{Phytoplankton pigments}

To obtain an indication of the components of the phytoplankton community that were not sampled in the $37 \mu \mathrm{m}$ mesh net samples, phytoplankton pigments were also examined. 
Fucoxanthin, the indicator pigment for diatoms, prymnesiophytes and chrysophytes, was detected at all 4 sites (Fig. 8). Concentrations ranged from 0 to $1.7 \mu \mathrm{g} \mathrm{l}^{-1}$ and were highest in the wet season at the 2 inshore sites ( $a$ and b), although they were often higher at Site b than at Site a. The fucoxanthin peaks mirrored the peaks in chl a (Fig. 3). Fucoxanthin concentrations at Sites $\mathrm{c}$ and d were considerably lower and did not vary seasonally. Concentrations at the bot- tom of the water column were generally close to those at mid-depth at all sites. Size fractionation showed that fucoxanthin was not restricted to the larger size fractions. In February 1991, for example, it was present equally in the 2 to 10 and greater than $10 \mu \mathrm{m}$ fractions (Table 5).

Zeaxanthin, the indicator pigment for cyanobacteria and prochlorophytes, was present at the 4 sites throughout the 2 yr of sampling (Fig. 8). Unlike fuco-

Table 3. Phytoplankton genera sampled with $37 \mu \mathrm{m}$ mesh nets in Albatross Bay, and their mean abundance at 4 sites from April 1986 to April 1992. Abundance based on 3 = dominant, 2 = common, 1 = rare. Cyano: cyanobacteria; Dino: dinoflagellate Prym: prymnesiophyte. "Subgenus. Codes for genera with a mean abundance $>0.100$ are used in Fig. 6

\begin{tabular}{|c|c|c|c|c|c|c|}
\hline Genus & Code & Class & $\begin{array}{c}\text { Mean } \\
\text { abundance }\end{array}$ & Genus & Class & $\begin{array}{c}\text { Mean } \\
\text { abundance }\end{array}$ \\
\hline Rhizosolenia & Rhiz. & Diatom & 2.099 & Diploneis & Diatom & 0.079 \\
\hline Chaetoceros & Chae & Diatom & 1.979 & Podolampas & Dino & 0.066 \\
\hline Thalassionema & Than & Diatom & 1.901 & Heteraulacus & Dino & 0.066 \\
\hline Trichodesmium & Tric & Cyano & 1.851 & Plagiogramma & Diatom & 0.054 \\
\hline Bacteriastrum & Bact & Diatom & 1.702 & Mastogloia & Diatom & 0.054 \\
\hline Nitzschia & Nitz & Diatom & 1.649 & Cerataulina & Diatom & 0.050 \\
\hline Thalassiosira & Thas & Diatom & 1.541 & Asterolampra & Diatom & 0.037 \\
\hline Coscinodiscus & $\operatorname{Cosc}$ & Diatom & 1.236 & Surirella & Diatom & 0.033 \\
\hline Thalassiothrix & That & Diatom & 1.186 & Pyrocystis & Dino & 0.033 \\
\hline Hemiaulus & Hemi & Diatom & 1.178 & Prorocentrum & Dino & 0.029 \\
\hline Pleurosigma & Pleu & Diatom & 1.087 & Gymnodinium & Dino & 0.029 \\
\hline Protoperidinium & Prpe & Dino & 1.083 & Ceratocorys & Dino & 0.029 \\
\hline Lauderia & Laud & Diatom & 0.921 & Zygabikodinium & Dino & 0.025 \\
\hline Paralia & Para & Diatom & 0.860 & Phaeocystis & Prym & 0.017 \\
\hline Odontella & Odon & Diatom & 0.860 & Campyloneis & Diatom & 0.017 \\
\hline Tripoceratium " & Trce & Dino & 0.855 & Amphipleura & Diatom & 0.017 \\
\hline Blepharocysta & Blph & Dino & 0.810 & Bellerochea & Diatom & 0.012 \\
\hline Detonula & Deto & Diatom & 0.806 & Epithemia & Diatom & 0.008 \\
\hline Dinophysis & Dinp & Dino & 0.603 & Bernadinium & Dino & 0.008 \\
\hline Amphiceratium & Amce & Dino & 0.554 & Raphoneis & Diatom & 0.004 \\
\hline Ceratium & Crtm & Dino & 0.525 & Plagiotropis & Diatom & 0.004 \\
\hline Diplopsalis & Dips & Dino & 0.492 & Peridiniopsis & Dino & 0.004 \\
\hline Eucampia & Euca & Diatom & 0.488 & Parahistioneis & Dino & 0.004 \\
\hline Gonyaulax & Gony & Dino & 0.483 & Noctiluca & Dino & 0.004 \\
\hline Leptocylindrus & Lept & Diatom & 0.463 & Histioneis & Dino & 0.004 \\
\hline Palmeria & Palm & Diatom & 0.434 & Heterodinium & Dino & 0.004 \\
\hline Amphiprora & Ampr & Diatom & 0.377 & Dissodinium & Dino & 0.004 \\
\hline Bacillaria & Bacp & Diatom & 0.343 & Balechina & Dino & 0.004 \\
\hline Planktoniella & Plan & Diatom & 0.335 & & & \\
\hline Streptotheca & Stth & Diatom & 0.326 & & & \\
\hline Asteromphalus & Astp & Diatom & 0.306 & & & \\
\hline Skeletonema & Skele & Diatom & 0.298 & & & \\
\hline Ditylum & Dity & Diatom & 0.264 & & & \\
\hline Corethron & Core & Diatom & 0.260 & & & \\
\hline Navicula & Navi & Diatom & 0.252 & & & \\
\hline Asterionella & Astn & Diatom & 0.252 & & & \\
\hline Climacodium & Clim & Diatom & 0.244 & & & \\
\hline Ornithocercus & Orni & Dino & 0.227 & & & \\
\hline Amphora & Amra & Diatom & 0.215 & & & \\
\hline Stephanopyxis & Step & Diatom & 0.198 & & & \\
\hline Actinoptychus & Acti & Diatom & 0.198 & & & \\
\hline Guinardia & Guin & Diatom & 0.178 & & & \\
\hline Pyrophacus & Pyph & Dino & 0.165 & & & \\
\hline Amphisolenia & Amph & Dino & 0.107 & & & \\
\hline
\end{tabular}


Table 4. Multivariate analysis of variance and significance tests for the effects of site, season and year on the abundance of $37 \mathrm{\mu m}$ mesh net phytoplankton genera. F statistics were approximated based on the Wilk's Lambda values. Two seasons were used: May to November (dry), and December to April (wet). $\mathrm{df}_{\text {num }}$ : degrees of freedom for numerator; $\mathrm{df}_{\text {den }}$ : degrees of freedom for denominator

\begin{tabular}{|lrrcc|}
\hline Variable & $\mathrm{df}_{\text {num }}$ & $\mathrm{df}_{\text {den }}$ & $F$ & $\mathrm{p}$ \\
\hline Site & 132 & 555 & 2.777 & 0.0001 \\
Season & 44 & 185 & 3.669 & 0.0001 \\
Year & 264 & 1110 & 3.105 & 0.0001 \\
Site $\times$ Season & 132 & 555 & 1.076 & 0.2842 \\
\hline
\end{tabular}

xanthin, it did not show a seasonal trend, and its concentrations were considerably lower $\left(0\right.$ to $0.23 \mu \mathrm{g} \mathrm{l}^{-1}$ ). Values obtained at mid-depth and bottom were similar at most sampling times. Despite the predominance of the large cyanobacterium Trichodesmium in the $37 \mu \mathrm{m}$ mesh net phytoplankton samples, size fractionation done in February 1991 showed that zeaxanthin was predominantly in the 2 to $10 \mu \mathrm{m}$ fraction (Table 5). Therefore, in addition to Trichodesmium, cyanobacteria in the nanoplankton and possibly Trichodesmium fragments are contributors to the phytoplankton biomass.

Chl $b$, the indicator pigment for green algae and prochlorophytes, was present at the 4 sites with few exceptions throughout the 2 yr of sampling (Fig. 8). There appeared to be a seasonal pattern at the inshore sites and concentrations were somewhat higher overall in 1991-92 than in 1990-91.

Chl a degradation products were not detected in any of the samples.

\section{Spatial variation}

The spatial variation in chl $a$, temperature and salinity was examined in more detail at 21 sites in Albatross Bay in February 1990. Temperature and salinity gradients were small, with a few exceptions, such as Sites 1 and 2 (Fig. 9). Chl a concentrations ranged from 0.06 to $4 \mathrm{ug} \mathrm{l}^{-1}$ and increased with depth at all sites with few exceptions (e.g. Site 1; Fig. 9).

Fucoxanthin (the indicator pigment for diatoms, prymnesiophytes and chrysophytes) was the dominant pigment at all sites. The trends mirrored that of chl $a$ : where chl a concentrations increased with depth, fucoxanthin concentrations also increased.

Size-fractionation studies were done in February 1991 to give an indication of the poten-

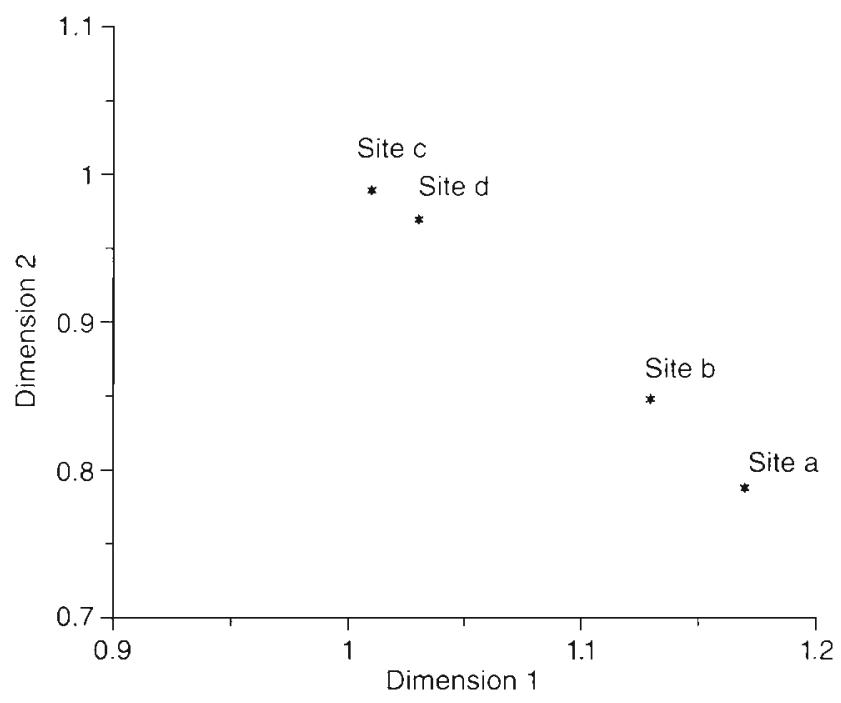

Fig. 5. Multidimensional scaling (MDS) ordination of Sites a, $b, c$ and $d$ based on the dimension coefficients (dimension 1 by dimension 2) of the abundance of large phytoplankton between April 1986 and April 1992

tial contribution of the smaller size fractions to the phytoplankton biomass that were not sampled with $37 \mu \mathrm{m}$ mesh nets. The highest proportion of chl a $\left(0.98 \mu \mathrm{g} \mathrm{l}^{-1}\right)$ was present in the 2 to $10 \mu \mathrm{m}$ fraction (Table 5). There was also a significant proportion in the $>10 \mu \mathrm{m}$ fraction $\left(0.35 \mu \mathrm{g} \mathrm{l}^{-1}\right)$.

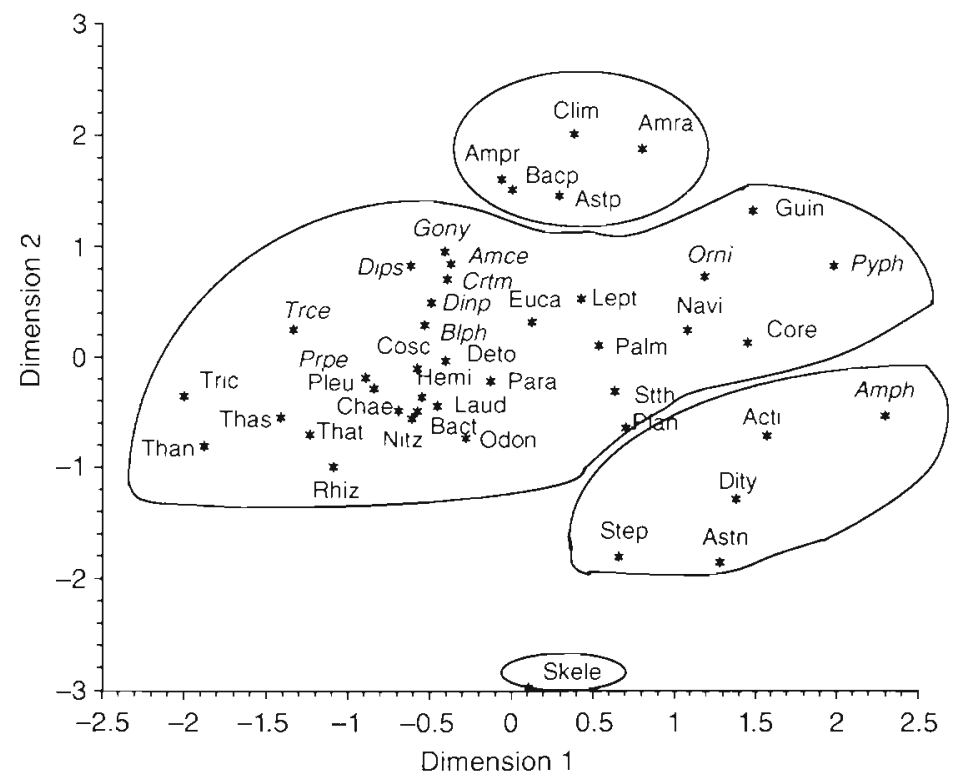

Fig. 6. MDS ordination of 44 phytoplankton genera based on the configuration of the scaling analysis for the period April 1986 to April 1992. For full genus names see Table 3 . Dinoflagellate genera codes are italicised 
Site a

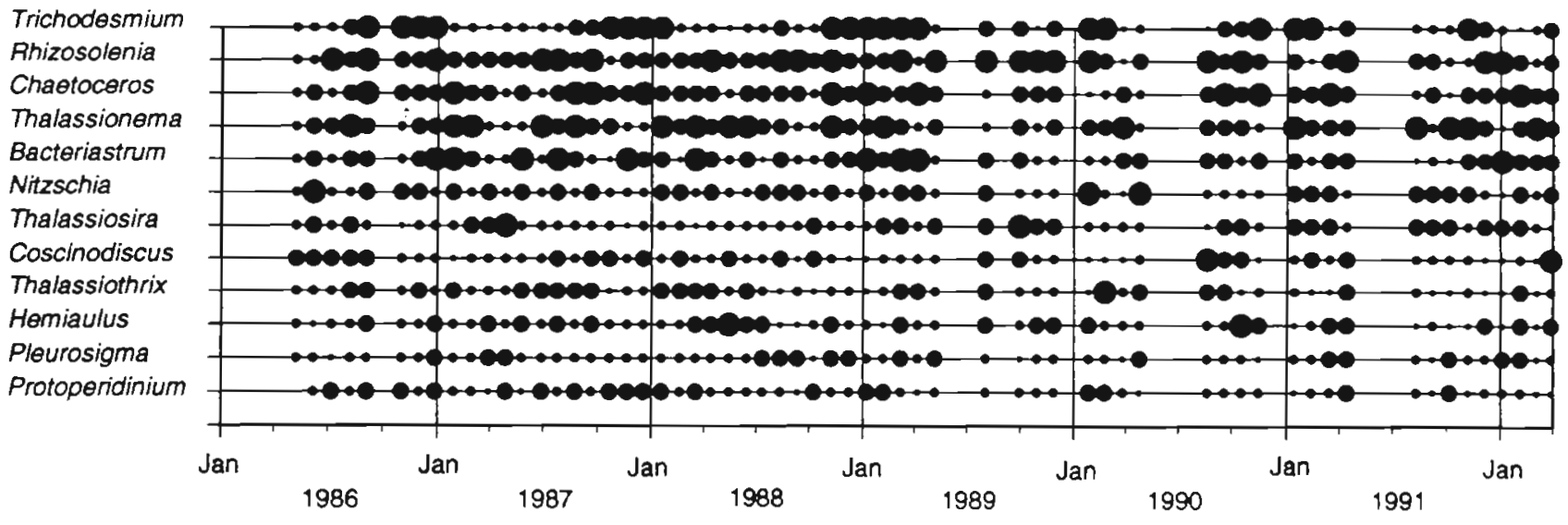

Site d

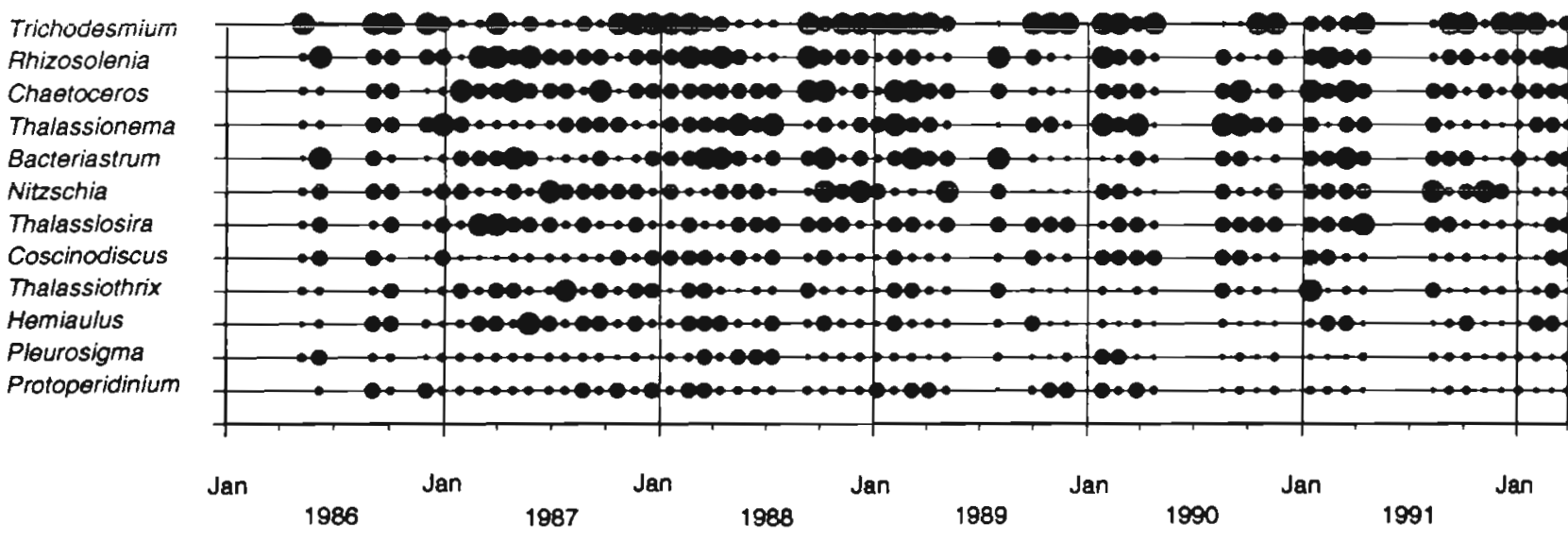

Fig 7. Bubble graph of the 12 dominant $37 \mu \mathrm{m}$ mesh net phytoplankton genera at 1 inshore (Site a) and 1 offshore (Site d) site in Albatross Bay from April 1986 to April 1992. Absent, rare, common and dominant categories are represented by 4 bubble sizes; bubble size increased with abundance. Months with no black dots denote no sampling

\section{DISCUSSION}

The Gulf of Carpentaria in northern tropical Australia has a climate characterised by wet and dry seasons. In Albatross Bay, in the east of the Gulf, around $70 \%$ of the rainfall falls between January and March. The rivers that empty into the Bay further reduce salinities. The winds in the wet season are lighter, moist northeast to northwest monsoons (Somers \& Long 1994); in the dry season, they are relatively strong, dry southeasterlies. Water temperatures are higher in the wet than in the dry season.

A coastal boundary layer separates the stratified deeper waters, which receive no terrestrial runoff, from the well-mixed coastal waters (Wolanski \& Ridd 1990, Rothlisberg et al. 1994). There is a region of upwelling, at 15 to $20 \mathrm{~m}$ depth, at this interface. It lies between the 2 inner sites ( $a$ and b) in Albatross Bay and the 2 outer sites ( $c$ and d).
The 2 inner sites had wet-season peaks in chl $a$ and generally had a higher phytoplankton biomass than the outer sites. Site b generally had higher chl a values than Site a, which might be due to its closeness to the region of upwelling, where nutrient availability would be enhanced by mixing

The wet season peaks in chl a at the inshore sites coincided with periods of higher rainfall and temperature. The increased freshwater input from estuaries might be providing nutrients for the phytoplankton; however, no systematic increase in nitrate+nitrite, phosphate and silicate concentrations was detected during the wet season and concentrations were not higher at the inshore sites. Wind mixing might also be stimulating phytoplankton growth by resuspending nutrients from the sediment, but the winds are stronger in the dry season than the wet season. Shortterm events, such as storms, also mix the water column. The resulting pulses in nutrients might not be 
Fucoxanthin

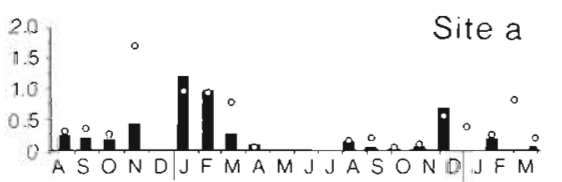

Zeaxanthin

Chlorophyll b
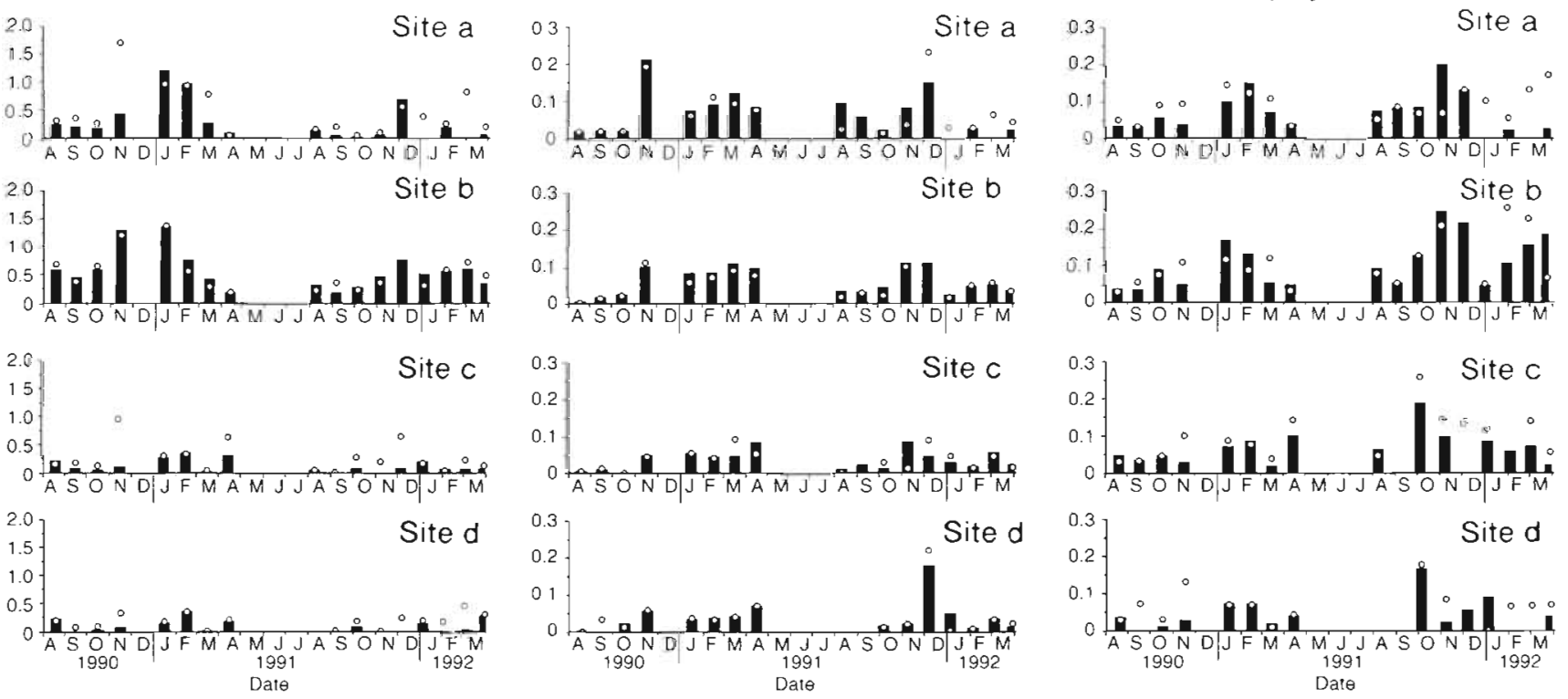

Fig. 8. Fucoxanthin, zeaxanthin and chl $b$ concentrations ( $a l l$ in $\mu \mathrm{g} \mathrm{l}^{-1}$ ) at 4 sites from August 1990 to March 1992 . Bars are middepth concentrations; ( 0 ) bottom concentrations. J: January; M: May; S: September. Months in which sampling did not occur have no bars

detectable by monthly sampling. Rainfall may also be stimulating growth by contributing micronutrients; however, they were not measured in this study.

Albatross Bay has low concentrations of nitrate+ nitrite $(0.76 \mu \mathrm{M})$; concentrations such as this are generally thought to be limiting to phytoplankton growth (Howarth 1988). In addition, the ratio of nitrate to phosphate present in the water column was low, i.e. 0.5 to 3 , compared with the N:P ratio required for phytoplankton growth of 16:1 (Redfield 1958). Ammonia concentrations were not measured in this study and it is possible that when this component of the inorganic nitrogen pool is taken into account the N:P ratio may be higher. However it is unlikely that the ammonia concentrations would be high enough to increase the N:P ratio to 16:1. Howarth (1988) has suggested that many marine systems are nutrient-limited, for example, phytoplankton in the central Great Barrier Reef are nitrogenlimited (Furnas \& Mitchell 1986).

Table 5. Albatross Bay, Gulf of Carpentaria: contributions of the $>10,2$ to 10 and 0.6 to $2 \mu \mathrm{m}$ size fractions to the chl $a_{\text {, }}$ fucoxanthin and zeaxanthin concentrations $\left(\mathrm{mg} \mathrm{l}^{-1}\right)$ at the top

$(0 \mathrm{~m})$ of the water column at Site a in February 1991

\begin{tabular}{|lccc|}
\hline Size fraction $(\mu \mathrm{m})$ & Chl $a$ & Fucoxanthin & Zeaxanthin \\
\hline 0.6 to 2 & 0.08 & 0 & 0.01 \\
2 to 10 & 0.98 & 0.21 & 0.07 \\
$>10$ & 0.35 & 0.21 & 0 \\
\hline
\end{tabular}

The concentration of chl a in Albatross Bay and its seasonal variation were similar to those found in other tropical coastal regions where eutrophication has not occurred. For example, on the west coast of Thailand, chl a concentrations are reported to range from 0.08 to $2.19 \mu \mathrm{g} \mathrm{l}^{-1}$ (Janekarn \& Hylleberg 1989); in the central Great Barrier Reef phytoplankton populations have a seasonal progression of abundance, being highest in summer, $2 \mathrm{\mu g} \mathrm{l}^{-1}$, than in winter, 0.25 to $0.5 \mathrm{\mu g} \mathrm{l}^{-1}$ (Furnas \& Mitchell 1986).

Chl a concentrations in Albatross Bay are higher (up to $\left.5.7 \mathrm{\mu g} \mathrm{l}^{-1}\right)$ than those in the deeper waters of the Gulf $\left(<1.5 \mu \mathrm{g} \mathrm{l}^{-1}\right.$ ) (Hallegraeff \& Jeffrey 1984, Rothlisberg et al. 1994). Many of the same $37 \mu m$ mesh net phytoplankton genera were observed in Albatross Bay and the central Gulf. For example, the cyanobacterium Trichodesmium was a dominant genus throughout the central Gulf (Hallegraeff \& Jeffrey 1984) and Albatross Bay. With few exceptions, the dominant diatom genera in the central Gulf also coincided with those in Albatross Bay. However, 7 genera found in Albatross Bay were not found in the deeper waters of the Gulf: the diatoms Amphipleura, Campyloneis, Epithemia and Plagiotropis, dinoflagellates Heteraulacus and Zygabikodinium, and the prymnesiophyte Phaeocystis.

Trichodesmium is also an important component of the phytoplankton in other tropical and subtropical regions (Revelante \& Gilmartin 1982, Hallegraeff \& Jeffrey 1984, Devassy \& Goes 1988). As in Albatross Bay, Trichodesmium has a high abundance in the 

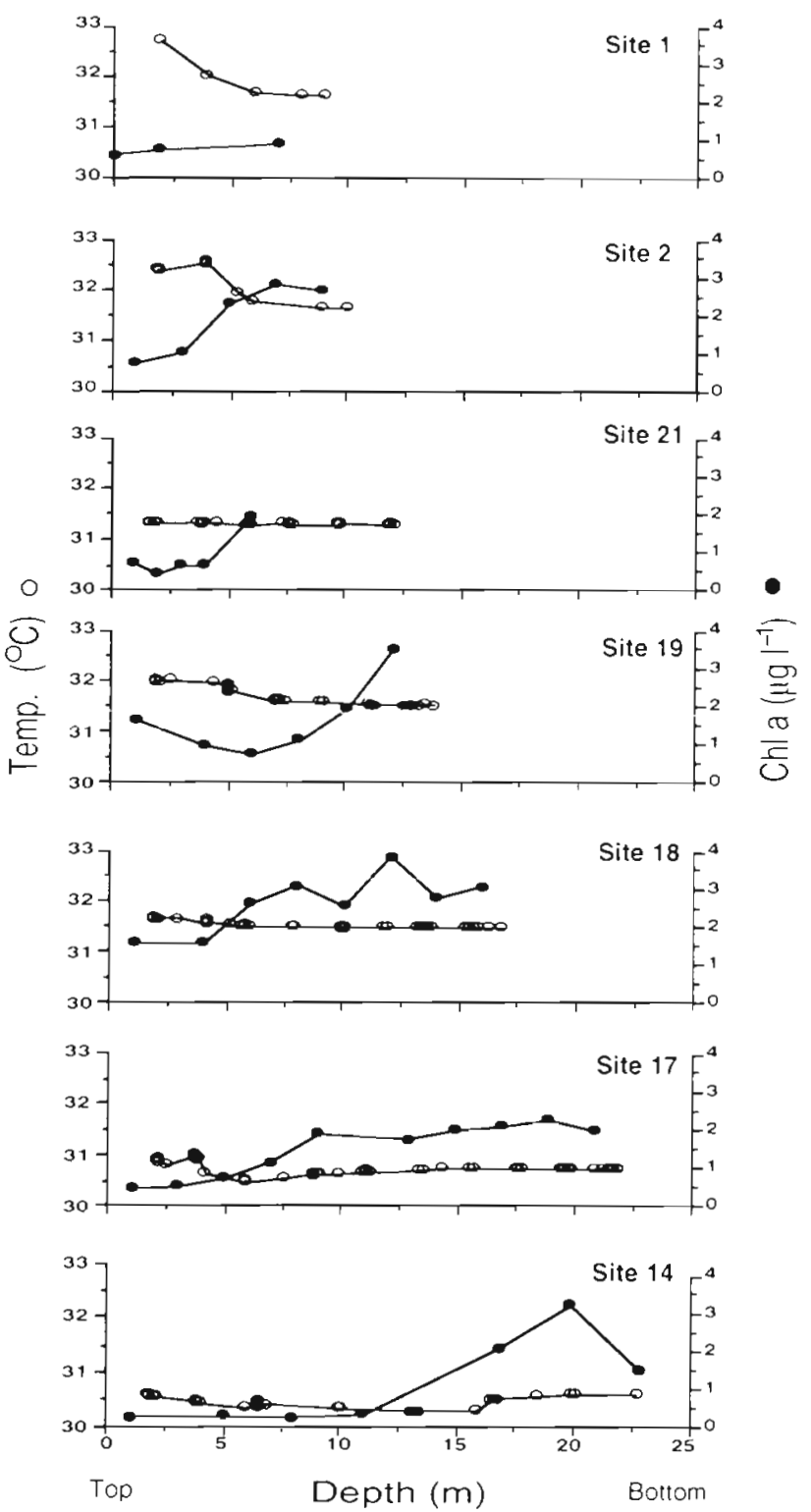

Fig. 9. Depth profiles of chl a concentrations $(\bullet)$ and temperature $(0)$ with depth at 7 sites in the northern transect sampled in Albatross Bay in February 1990 (see Fig. 1b)

Great Barrier Reef lagoon from August to January. Extended calm conditions seem to be most conducive to the formation of Trichodesmium blooms since mixing created by wind tends to break up the bundles formed in the bloom (Revelante \& Gilmartin 1982). These bundles appear to be necessary for nitrogen fixation (Bryceson \& Fay 1981), however, the mechanism has not been established (Carpenter et al. 1990). In Albatross Bay Trichodesmium bloomed during relatively calm periods in the wet season, and the most extended blooms occurred in the years when there was little or no wind. Revelante \& Gilmartin (1982) found an inverse relationship between Trichodesmium and diatom numbers and diversity in the Great Barrier Reef, which suggested Trichodesmium has a negative impact on the growth of other phytoplankton. However, this relationship was not apparent in Albatross Bay and Trichodesmium may, in fact, be enhancing growth, because it is capable of fixing nitrogen and therefore provides a source of nitrogen for other phytoplankton (Carpenter \& Romans 1991). Capone \& Carpenter (1982) calculated that Trichodesmium contributes about $25 \%$ of the total estimated nitrogen fixation in the sea, illustrating its importance in the marine nitrogen cycle.

Continental shelf areas generally have higher proportions of large phytoplankton than small species (Malone 1980). These phytoplankton are generally highly variable in abundance, which may be related to pulses in the biomass of diatoms. In contrast to the distunct succession patterns observed in temperate regions of the world (Guillard \& Kilham 1977, Hallegraeff \& Jeffrey 1993), the diatoms in Albatross Bay did not show a seasonal pattern of succession. Succession patterns are often determined by the loss of diatoms through diffusion, sinking and grazing, as well as the rate of nutrient regeneration. The lack of a succession pattern in Albatross Bay may be related to the absence of major physical or chemical triggers which generally precipitate a systematic species succession, i.e. the temperature and salinity changes were not dramatic, and nutrient concentrations were generally low.

The abundance and successional changes in the phytoplankton community are generally linked to those of the herbivorous copepod community (Heinrich 1962). In temperate waters this has a seasonal cycle with the biomass of phytoplankton increasing in spring followed by a higher abundance of zooplankton. By contrast, in the Gulf of Carpentaria a 2 yr study of copepod abundance showed that there was no seasonal variation and a generally low abundance $(\mathrm{J}$. G. Greenwood pers. comm.). This is consistent with the lack of a successional pattern in the phytoplankton community and hence the relatively stable nature of these waters.

The $37 \mu \mathrm{m}$ mesh net phytoplankton was dominated by Rhizosolenia, a genus that is symbiotic with the nitrogen-fixing cyanobacterium Richelia, particularly when nutrient concentrations are low (Guillard \& Kilham 1977), as they are in Albatross Bay. Possibly this strategy for obtaining nitrogen for growth explains the dominance of Rhizosolenia. The other dominant diatoms in the $37 \mu m$ mesh net phytoplankton fraction in Albatross Bay - Chaetoceros, Thalassionema and Bacteriastrum - also commonly dominate coastal waters in the tropics and subtropics throughout the world (Devassy \& Goes 1988, Maclean 1989). 
The dominance of diatoms in Albatross Bay may be related to the concentration of silicate. Egge \& Aksnes (1992) showed that in experiments diatoms were dominant irrespective of season if the silicate concentration exceeded approximately $2 \mu \mathrm{M}$. Concentrations of silicate in Albatross Bay were generally higher than this The high growth rate of diatoms, i.e. 5 to $50 \%$ faster than other algal classes (Egge \& Aksnes 1992), and the abundant silicate in the Bay, may explain the preponderance of diatoms.

The size-fractionation and pigment studies showed that there is a significant nanoplankton fraction (i.e. $<10 \mu \mathrm{m}$ ) in Albatross Bay. It includes Navicula jeffreyi, Minutocellus polymorphus and Pseudostaurosira shiloi, which were not observed in the $37 \mu \mathrm{m}$ mesh net phytoplankton samples (Hallegraeff \& Burford in press).

The relative contributions of the phytoplankton classes of all sizes to the overall algal biomass has been approximated by Everitt et al.'s (1990) method of using pigment indicator ratios: chl a:fucoxanthin of 1.4 , chl $a$ : zeaxanthin of 1.7 , chl $a$ : chl $b$ of 0.75 . By multiplying the pigment concentration by the ratios, its contribution to the chl a concentration can be determined. The average percentage contributions of fucoxanthin. zeaxanthin and chl $b$ at the inshore sites were 66,9 and $6 \%$ respectively over the 2 yr that HPLC pigment analysis was done. The high concentrations of fucoxanthin confirm that the phytoplankton community is diatom rich. In contrast, the offshore sites had a lower proportion of diatoms, a similar proportion of cyanobacteria and a higher proportion of green flagellates, i.e. $46 \%$ fucoxanthin, $11 \%$ zeaxanthin and $12 \% \mathrm{chl} b$. The deeper waters of the Gulf generally have a larger and more stable nanoplankton component (Hallegraeff \& Jeffrey 1984, Rothlisberg et al. 1994). These small size fractions do not undergo marked seasonal cycles (Furnas \& Mitchell 1986).

Albatross Bay is a spawning ground for the banana prawn Penaeus merguiensis and tiger prawn $P$. semisulcatus. There are 2 peaks of reproduction in the Bay: spring and autumn. The resulting larvae feed exclusively on phytoplankton during the first week of growth (Dall et al. 1990). The abundance of larvae varies considerably from year to year (Rothlisberg et al. 1988), but in 6 yr larval numbers did not correlate with chl a concentrations. Short-term feeding experiments have also been conducted in Albatross Bay in spring and autumn with $P$. merguiensis larvae reared in in situ cages (Preston et al. 1992). They confirmed that the diatom-rich community present at these times provided a nutritionally adequate food source for prawn larvae. In contrast the cyanobacterium genus Trichodesmium, which is dominant in Albatross Bay, appears to have a negative effect on larval growth (N. P. Preston unpubl. data). This effect was examined by feeding a Trichodesmium species to prawn larvae in the laboratory and measuring larval growth and survival. In short-term trials, larval survival was not affected but the growth rate was reduced. However the extent to which Trichodesmium affects larval growth and mortality in Albatross Bay is unknown.

In summary, Albatross Bay has summer peaks in phytoplankton biomass, probably caused by a combination of higher temperatures, increased rainfall and calmer weather. It is a relatively stable environment in terms of the lack of seasonal succession in the diatomdominated phytoplankton community, low nutrients and the dominance of phytoplankton species commonly associated with nutrient-depleted waters (e.g. Rhizosolenia). The cyanobacterium genus Trichodesmium was an exception: its seasonal peaks in abundance appear to be linked to calmer weather conditions. The deeper waters out from Albatross Bay had phytoplankton biomass and species composition similar to those in the central Gulf.

Acknowledegments. We thank the following for their assistance: the Captain and crew of the FV 'Jacqueline D'; Peter Crocos, Michael Haywood, Christopher Jackson, David Moriarty, Robert Pendrey, Peter Pollard, Nigel Preston and Tonya van der Velde for collecting samples; Kerry Clarke, Andrew Letchford, Troy Richardson and Riku Koskela for analysing samples; Gustaaf Hallegraeff for establishing the protocol for sampling and identifying the $37 \mathrm{\mu m}$ mesh net phytoplankton; Christopher Jackson for developing and managing the databases for the biological, chemical and physical data; John Parslow, Gustaaf Hallegraeff and Vivienne Mawson for constructive criticism of the manuscript. This work was supported by Fishing Industry Research and Development Trust Account Grants (FIRDTA 85/85 and 89/13).

\section{LITERATURE CITED}

Allen, W. E., Cupp, E. E. (1935). Plankton diatoms of the Java Sea. A. Jard. bot. Buitenzorg. 44: 101-174

Bryceson, I., Fay, P. (1981). Nitrogen fixation in Oscillatoria (Trichodesmium) erythreae in relation to bundle formation and trichome differentiation. Mar. Biol. 61. 159-166

Burford, M A., Pollard, P. C. (1994). Pigment contaminants in polycarbonate filters. Mar. Ecol. Prog. Ser. 103: 203-206

Burford, M. A., Long, B. G., Rothlisberg, P. C. (1994). Sedimentary pigments and organic carbon in relation to microalgal and benthic faunal abundance in the Gulf of Carpentaria. Mar. Ecol. Prog. Ser. 103: 111-117

Capone, D. G., Carpenter, E. J. (1982). Nitrogen fixation in the marine environment. Science 217: 1140-1142

Carpenter, E. J., Chang, J., Cottrell, M., Schubauer, J., Paerl, H. W., Bebout, B. M., Capone, D. G. (1990). Re-evaluation of nitrogenase oxygen-protective mechanisms in the planktonic marine cyanobacterium Trichodesmium. Mar Ecol. Prog. Ser. 65: 151-158

Carpenter, E. J., Romans, K. (1991). Major role of the cyanobacterium Trichodesmium in nutrient cycling in the North Atlantic Ocean. Science 254: 1356-1358

Clarke, K. R. (1993). Non-parametric multivariate analysis of 
changes in community structure. Aust. J. Ecol. 18 $117-143$

Dall, W., Hill, B. J., Rothlisberg, P. C., Staples, D. J. (1990) Biology of the Penaeidae. Advances in marine biology, Vol. 27. Academic Press, London

Devassy, V. P., Goes, J. I. (1988). Phytoplankton community structure and succession in a tropical estuarine complex (central west coast of India). Estuar. coast. Shelf Sci. 27 : 671-685

Egge, J. K., Aksnes, D. L. (1992). Silicate as regulating nutrient in phytoplankton competition. Mar. Ecol. Prog. Ser. 83: $281-289$

Everitt, D. A., Wright, S. W., Volkman, J. K., Thomas, D. P., Lindstrom, E. J. (1990). Phytoplankton community compositions in the western equatorial Pacific determined from chlorophyll and carotenoid pigment distributions. Deep Sea Res. 37: 975-997.

Field, J. G., Clark, K. R., Warwick, R. M. (1982). A practical strategy for analysing multispecies distribution patterns. Mar. Ecol. Prog. Ser. 8: 37-52

Furnas, M. J., Mitchell, A. W. (1986). Phytoplankton dynamics in the Creat Barrier Reef I. Seasonal changes in biomass and community structure and their relation to intrusive activity. Cont. Shelf Res. 6: 363-384

Guillard, R. L., Kilham, P. (1977). The ecology of the marine planktonic diatoms. In: Werner, D. (ed.) The biology of diatoms. Botanical Monographs, Vol. 13. Blackwell Scientific Publications, Oxford, p. 372-469

Hallegraeff, G. M., Burford, M. A. (in press). Some new of little known nanoplankton diatoms cultured from tropical and subtropical Australian shelf waters. Beih. Nova Hedwigia

Hallegraeff, G. M., Jeffrey, S. W. (1984). Tropical phytoplankton species and pigments of continental shelf waters of north and north-west Australia. Mar. Ecol. Prog. Ser. 20: $59-74$

Hallegraeff, G. M., Jeffrey, S. W. (1993). Annually recurrent diatom blooms in spring along the New South Wales coast of Australia. Aust. J. mar. Freshwat. Res. 44: 325-334

Heinrich, A. K. (1962). The life histories of plankton animals and seasonal cycles of plankton communities in the oceans. J. Cons. int. Explor. Mer 27: 15-24

Heron, A. C. (1982). A vertical free fall plankton net with no mouth obstructions. Limnol. Oceanogr. 27: 380-383

Howarth, R. W. (1988). Nutrient limitation of net primary production in marine ecosystems. A. Rev. Ecol. 19: 89-110

Janekarn, V., Hylleberg, J. (1989). Coastal and offshore primary production along the west coast of Thailand

This article was submitted to the editor
(Andaman Sea) with notes on physical-chemical variables. Phuket mar. Biol. Center Res. BulI. 51

Maclean, J. L. (1989). Red tides in Papua New Guinea waters. In: Hallegraeff, G. M., Maclean, J. L. (eds.) Biology, epidemiology and management of Pyrodinium red tides. ICLARM Conference Proceedings 21 International Centre for Living Aquatic Resources Management, Manila, and Fisheries Dept, Ministry of Development, Brunci Darussalam, p. 27-38

Malone, T.C. (1980). Algal size. In: Morris, I. (ed.) The physiological ecology of phytoplankton. Blackwell Scientific Publications, Oxford, p. 433-436

Preston, N. P., Burford, M. A., Coman, F. E., Rothlisberg, P. C. (1992). Natural diet of larval Penaeus merguiensis (Decapoda: Penaeidae) and its effect on survival. Mar. Biol. 113: $181-191$

Redfield, A. C. (1958). The biological control of chemical factors in the environment. Am. Sci. 46: 205-222

Revelante, N., Gilmartin, M. (1982). Dynamics of phytoplankton in the Great Barrier Reef Lagoon. J. Plankton Res. 4: $47-76$

Rothlisberg, P. C., Crocos, P. J., Staples, D. J. (1988). Recruitment dynamics of penaeid prawns in Albatross Bay, Gulf of Carpentaria. In: Proceedings, Australian Marine Sciences Association, Silver Jubilee Conference. Wavelength Press, Sydney, p. 37-41

Rothlisberg, P. C., Pollard, P. C., Nichols, P. D., Moriarty, D. J. W., Forbes, A. M. G., Jackson, C. J., Vaudrey, D (1994). Phytoplankton community structure and productivity in relation to the hydrological regime of the Gulf of Carpentaria in summer. Aust. J. mar. Freshwat. Res. 45 265-282

Seber, G. A. F. (1984). Multivariate observations. John Wiley \& Sons, New York

Somers, I. F., Long, B. G. (1994). A note on the sediments and hydrology of the Gulf of Carpentaria, Australia. Aust. J. mar. Freshwat. Res. 45: 283-292

Strickland, J. D. H., Parsons, T. R. (1972). A practical handbook of seawater analysis. Bull. Fish. Res. Bd Can. 167

Taylor, F. J. R. (1976). Dinoflagellates from the International Indian Ocean Expedition. A report on material collected by the R.V 'Anton Bruun' 1963-64. Bibl. Bot. 132: $1-234$

Wolanski, E., Ridd, P. (1990). Mixing and trapping in Australian tropical coastal waters. In: Cheng, R. T (ed.) Residual currents and long-term transport. Coastal and Estuarine Studies Vol. 38. Springer-Verlag, New York, p. $165-183$

Manuscript first received: August 15, 1994

Revised version accepted: December 8, 1994 